\title{
IMPLEMENTASI SISTEM AKUAPONIK SEBAGAI MEDIA PEMBELAJARAN UNTUK MENINGKATKAN HASIL BELAJAR SISWA DI MTS. ZAINUL HASAN BALUNG
}

\author{
${ }^{1}$ Nuriyatul Laili, ${ }^{2}$ Umi Nurjanah, ${ }^{3}$ Miftahul Hakim \\ ${ }_{123}$ Pendidikan Biologi, Universitas Islam Jember \\ 1lailynuriyatul@gmail.com,2kholidumi@gmail.com, ${ }^{3}$ cak.kiem81@gmail.com
}

\begin{abstract}
ABSTRAK
Pembelajaran IPA Terpadu pada kompetensi dasar interaksi mahluk hidup dengan lingkungan yang berlangsung belum ada media dalam pembelajaran, berdasarkan Penilaian Harian $61,2 \%$ yang mecapai ketuntasan, oleh karena itu untuk meningkatkan hasil belajar siswa peneliti menerapkan sistem akuaponik sebagai media pembelajaran. Tujuan penelitian Untuk mengetahui peningkatan hasil belajar siswa kelas VII.C di MTs. Zainul Hasan Balung, melalui implementasi sistem akuaponik sebagai media pembelajaran. Jenis penelitian ini adalah penelitian tindakan kelas (PTK). Subyek dalam penelitian ini seluruh siswa kelas VII.C MTs. Zainul Hasan Balung yang berjumlah 31 siswa. Metode pengambilan data yang digunakan dalam penelitian ini adalah tes hasil belajar, wawancara, dan observasi. Analisis data kuantitatif diperoleh dari tes hasil belajar siswa setiap akhir siklus. Indikator keberhasil diukur dengan persentase ketuntasan klasikal 75\% dan nilai KKM 70 . Penelitian dilakukan dalam 2 siklus. Setiap siklus terdiri dari 2 pertemuan. Hasil penelitian menunjukkan pada akhir tindakan terjadi peningkatan hasil belajar mencapai ketuntasan klasikal 90,3\%.
\end{abstract}

Kata Kunci: Media Sistem Akuaponik, Hasil Belajar.

\section{ABSTRACT}

Nowadays, no learning media are existing in the context of Integrated Science teaching and learning, particularly in the basic competency of interactions between live-creatures and the environment. According to the daily assessment, there are $61.2 \%$ of students have reached the target of achievement. Therefore, the student-researcher applies the Aquaponic System as the learning media to increase achievement. This study aims to find out the increasing of students' achievement in the class of VIII- C of MTs Zainul Hasan, Balung through the implementation of Aquaponic System as the learning media. The design of this study utilizes Classroom Action Research to all of the students (n=31) in VIII-C of MTs Zainul Hasan, Balung. The data collection method is from students' achievement test, interview, and observation. Quantitative data were obtained from students' achievement tests at every end of the phase. The indicator of achievement was measured by $75 \%$ of classical completion percentage and the minimum standard of completion of 70 . This research involves two phases in which two meetings for each phase. The result of this research indicates the increase of the students' achievement that was $90.3 \%$ classical completion.

Keywords: Aquaponic System learning media, students' achievement

\section{PENDAHULUAN}

Proses pembelajaran IPA Terpadu seharusnya berkaitan dengan cara mencari tahu tentang alam secara sistematis, sehingga IPA Terpadu bukan hanya penguasaan kumpulan pengetahuan yang berupa fakta-fakta, konsep-konsep, atau prinsip-prinsip saja tetapi juga merupakan suatu proses penemuan. Pendidikan IPA diharapkan dapat menjadi wahana bagi peserta didik untuk mempelajari diri sendiri dan alam sekitar, serta prospek pengembangan lebih lanjut dalam menerapkannya di dalam kehidupan sehari-hari. Proses pembelajarannya menekankan pada pemberian pengalaman langsung untuk mengembangkan kompetensi agar menjelajahi dan memahami alam sekitar secara ilmiah. (Listyawati, 2012).

Kenyataan yang dijumpai di lapangan, dari hasil wawancara yang telah di lakukan di MTs. Zainul Hasan Balung Kabupaten Jember yang dilaksanakan pada hari Rabu, tanggal 13 November 2019, dengan Guru Mata Pelajaran IPA 
Terpadu Kelas VII.C diperoleh informasi bahwa terdapat 31 siswa dengan 11 siswa laki-laki dan 20 siswa perempuan, dimana pembelajaran IPA Terpadu menggunakan metode ceramah serta belum ada media dalam pembelajaran dan untuk KKM (Kriteria Ketuntasan Maksimal) mata pelajaran IPA Terpadu yaitu 70, berdasarkan Penilaian Harian pada Kompetensi Dasar Materi Interaksi Mahluk Hidup dengan Lingkungan sebelumnya diperoleh data 19 siswa yang tuntas dan 12 siswa yang belum tuntas dari 31 siswa sehingga dapat diporsentasekan $61,2 \%$ yang mecapai ketuntasan dari data wawancara mendapati hasil bahwa hasil belajar siswa masih rendah.

Berdasarkan permasalahan diatas diperlukan media pembelajaran yang bersifat menekankan pada pemberian pengalaman untuk membantu proses pembelajaran. Media pembelajaran ini dapat digunakan oleh siswa dalam penelitian/praktikum. Salah satu media pembelajaran yang sesuai yakni media pembelajaran berbasis sitem aquaponik. Dimana sistem aquaponik adalah sebuah sistem biologis tepadu yang menghubungkan resirkulasi akultur dengan sayuran hidropinik, bunga, maupun produksi herbal. Hal tersebut menciptakan ekositem yang berkelanjutan di mana kedua tanaman dan ikan dapat berkembang (Ristiawan, 2012). Penelitian sebelumnya oleh Istiqomah Aminin (2019) menggunakan Media Akuaponik untuk Meningkatkan Hasil Belajar Filtrasi Air Pada Siswa Kelas 6, hasil dari penelitian tersebut menunjukkan pada akhir tindakan terjadi peningkatan hasil belajar filtrasi air mencapai ketuntasan klasikal diatas $78 \%$..

Berdasarkan latar belakang dan penelitian sebelumnya yang telah dilaksanakan memperkuat peneliti melakukan penelitian tindakan kelas dengan judul "Implementasi Sistem
Akuaponik sebagai Media Pembelajaran untuk Meningkatkan hasil belajar siswa di MTs. Zainul Hasan Balung".

\section{METODE PENELITIAN}

Jenis penelitian ini merupakan penelitian tindakan Kelas (PTK). Langkah-langkah penelitian tindakan kelas ini meliputi: tahap persiapan, diagnostik, perencanaan tindakan kelas, untuk memecahkan masalah.

Penelitian ini dirancang menjadi 2 siklus yang pada setiap siklusnya meliputi: perencanaan, tindakan, observasi, evaluasi, dan refleksi.

Ketika siklus satu tidak memenuhu indikator keberhasilan maka akan diulang kembali disiklus dua dengan perlakuan yang sama menggunakan media sistem akuaponik, dan penelitian akan diakhiri setelah siklus dua diselesaikan. Indikator kebeerhasilan yang dimaksud adalah memenuhi target yang ditentukan klasikal yaitu 75\% serta memperoleh nilai $\geq 70$ sesuia KKM yang ditentukan.

Subyek dalam penelitian ini adalah seluruh siswa kelas VII.C MTs. Zainul Hasan Balung yang berjumlah 31 siswa.

Analisis kuantitatif digunakan untuk menganalisis data yang diperoleh dari hasil belajar siswa setiap siklusnya. Analisis kuantitatif dihitung dengan menggunakan rumus sebagai berikut:

a. Nilai hasil belajar kognitif siswa dihitung dengan menggunakan rumus berikut:

$\frac{\text { Jumlah skor yang diperoleh siswa }}{\text { Jumlah skor Maksimal }} \times 100$

(Sumber : Priyayi, 2017)

b. Ketuntasan belajar siswa secara

klasikal dihitung dengan

menggunakan rumus:

$\frac{\text { Jumlah Siswa Tuntas KKM }}{\text { Jumlah Total Siswa }} \times 100 \%$

(Sumber : Priyayi, 2017)

Sebagai acuan untuk mengukur kriteria ketuntasan hasil belajar siswa sebagai berikut; 


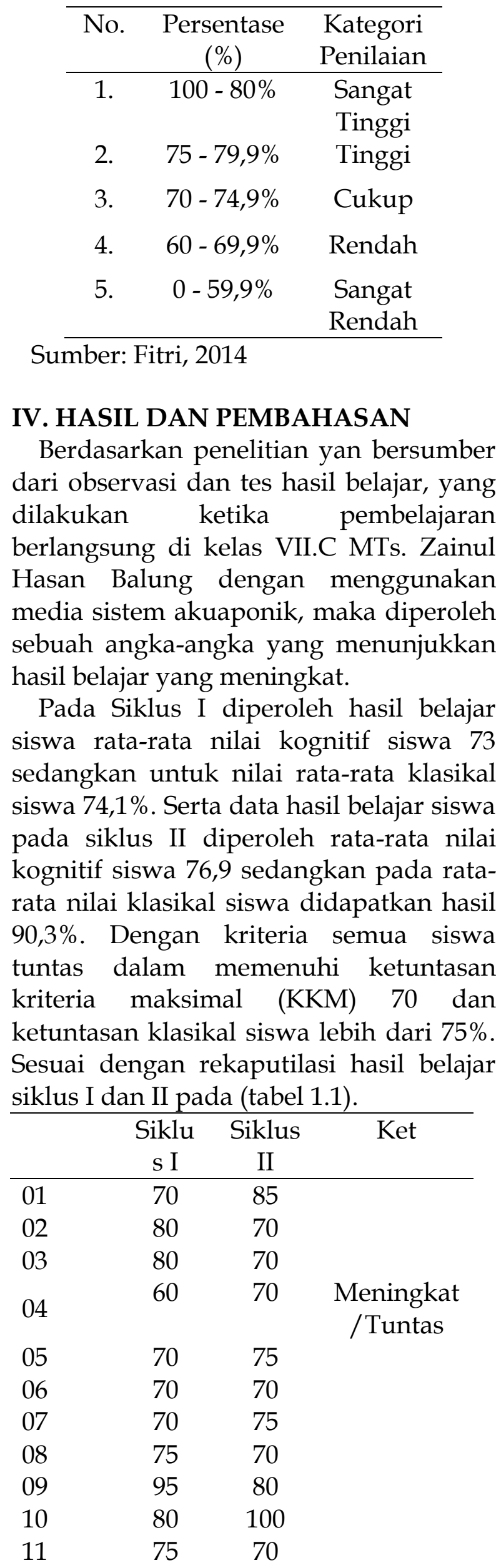

\begin{tabular}{|c|c|c|c|}
\hline 12 & 65 & 65 & $\begin{array}{l}\text { TIDAK } \\
\text { TUNTAS }\end{array}$ \\
\hline 13 & 70 & 70 & \\
\hline 14 & 55 & 90 & $\begin{array}{c}\text { Meningkat } \\
\text { /Tuntas }\end{array}$ \\
\hline 15 & 70 & 75 & \\
\hline 16 & 95 & 80 & \\
\hline 17 & 70 & 70 & \\
\hline & 50 & 50 & TIDAK \\
\hline 18 & & & TUNTAS \\
\hline 19 & 60 & 80 & \\
\hline 20 & 75 & 80 & \\
\hline 21 & 70 & 70 & \\
\hline 22 & 70 & 100 & \\
\hline 23 & 90 & 80 & \\
\hline 24 & 100 & 100 & \\
\hline 25 & 95 & 100 & \\
\hline 26 & 70 & 70 & \\
\hline & 65 & 85 & Meningkat \\
\hline 27 & & & /Tuntas \\
\hline 28 & 90 & 70 & \\
\hline 29 & 50 & 65 & TIDAK \\
\hline 30 & 70 & 80 & \\
\hline 31 & 50 & 70 & $\begin{array}{c}\text { Meningkat } \\
\text { /Tuntas }\end{array}$ \\
\hline Jumlah & 2265 & 2385 & \\
\hline $\begin{array}{l}\text { Rata- } \\
\text { rata }\end{array}$ & 73 & 76,9 & \\
\hline Nilai & 74,1 & $90,3 \%$ & \\
\hline $\begin{array}{l}\text { Ketunt } \\
\text { asan }\end{array}$ & $\%$ & & \\
\hline Klasika & & & \\
\hline 1 & & & \\
\hline
\end{tabular}

\section{KESIMPULAN}

Berdasarkan hasil Penelitian Tindakan Kelas menggunakan Media Sistem Akuaponik dapat disimpulkan bahwa penggunaan Media Sistem Akuaponik dapat meningkatkan hasil belajar siswa kelas VII.C MTs. Zainul Hasan Balung, dengan hasil belajar Pra Siklus terdapat 19 siswa yang tuntas dan 12 siswa belum tuntas sehingga persentase ketuntasan klasikal siswa 61,2 \%, dan meningkat pada perlakuan siklus I dengan 23 siswa yang tuntas dan 8 siswa yang belum 
tuntas sehingga porsentase ketuntasan klasikal siswa mencapai $74,1 \%$, pada siklus I masih belum memenuhi target indikator capaian dimana yang seharusnya $75 \%$, peningkat yang baik terjadi pada siklus II dengan 28 siswa tuntas dan 3 siswa yang masih belum tuntas dengan persentase nilai klasikal $90,3 \%$.

\section{DAFTAR PUSTAKA}

Aimah, Muslikhatun. 2017. Penggunaan Aplikasi Macromedia Flash 8 Sebagai Media Pembelajaran Interaktif Untuk Meningkatkan Hasil Belajar Siswa. Bioshell Vol.6 No.01 2017

Aminin, Istiqomah. 2019.“Penggunaan Media Aquaponik Dalam Meningkatkan Hasil Belajar Filtrasi Air Pada Siswa Kelas 6 (Enam). Jurnal Manajemen dan Supervisi Pendidikan (JMSP) Vol. 3 Tahun 2019.

Arikunto. 2010. Prosedur Penelitian Suatu Pendekatan Praktik. Jakarta: Rineka Cipta.

Arianti, Yulia. 2019. “Pengembangan Buku Penuntun Praktikum Makhluk Hidup dan Lingkungan Dengan Model Argument- Driven Inquiry (Adi) Untuk Siswa SMP / MTs Kelas VII di Bandar Lampung".

Campbell, dkk. 2008. Biologi Edisi Kedelapan Jilid 3. Jakarta: Erlangga.

Fitri, Nurul. 2014. "Penggunaan Model Pembelajaran Group Investigation Untuk Meningkatkan Hasil Belajar Siswa Kelas X1 Pada Materi Ekosistem di SMA Negeri 1 Kuta Baro Aceh Besar".

Hendriawan, Deri dan Usmaedi. 2019 "Penerapan Pembelajaran Higher Order Thingking Skills (HOTS) Di Sekolah Dasar". Jurnal Pendidikan Dasar Setiabudhi, Vol. 2 Tahun 2019.

Hutauruk, Pindo dan Rinci Simbolon. 2018. "Meningkatkan Hasil Belajar Siswa Dengan Alat Peraga Pada Mata Pelajaran IPA Kelas IV SDN Nomor 14 Simbolon Purba". School Education Journal (SEJ) Vol.8 No 2 Juni 2018.
Isyuniarsih. 2012. Peningkatan hasil belajar kognitif, Afektif daan psikomotorik pada mata Pelajaran IPA. https://www. google.com/search?q=jurnal+hasil+belaj ar+kognitif\%2Cpsikomotork $\% 2 \mathrm{C}+$ afktif $\underline{\text { \&ie }=\text { utf8\&oe }=\text { utf8\&client }=\text { frefox-b }}$ (Online) 14 Desember 2019.

Jihad, Asep dan Haris Abdul. 2013.Evaluasi Pembelajaran. Jogyakarta: Multi Pressido. Jumhana, N. 2010. Modul 9: Makhluk Hidup dan Lingkungan.(http:/ / file.upi.edu/Direkto ri/FIP/JUR._PEND._LUAR_BIASA/195 90501984031NNA_JUMHANA/modul_1 engkap/Modul_9_MAKHLUK_HIDUP DAN_LINGKUGAN.pdf), (Online). diakses 30 Desember 2019.

Listyawati, M. 2012. Pengembangan Perangkat Pembelajaran IPA Terpadu di SMP. Semarang JISE UNNES.

Mahnun, Nunu. 2012. “Media Pembelajaran (Kajian terhadap Langkah-langkah Pemilihan Media dan Implementasinya dalam Pembelajaran". Dalam Jurnal Pemikiran Islam Vol. 372012.

Marsela, Fatimaha. 2018. “Sistem Akuaponik Dengan Limbah Kolam Ikan Lele Untuk Memproduksi Sayuran Organik".

Miftah, M. 2013 “Fungsi , dan Peran Media Pembelajaran sebagai Upaya Peningkatan Kemampuan Belajar Siswa". Jurnal KWANGSAN Vol. 1 Nomor 2, Desember 2013.

Priyayi, D. F. 2017. “Peningkatan Hasil Belajar Kognitif Pada Pembelajaran Biologi Siswa Kelas XI IPA 2 SMA Negeri 1 Pabelan Melalui Penerapan Model Project Based Learning".

Purwanto, 2011. Evaluasi Hasil Belajar, Yogyakarta: Pustaka Pelajar.

Ristiawan, Agung Nugroho. 2012. Aplikasi Teknologi Aquaponic Pada Budidaya Ikan Air Tawar Untuk Optimalisasi Kapasitas Produksi. Jurnal Saintek Perikanan Vol. 8. No. 1, 2012.

Setiowati, Hanifah, 2015. “Penerapan Model Pembelajaran Inkuiri Terbimbing (Guided Inquiry) Dilengkapi LKS Untuk 
Meningkatkan Aktivitas danPrestasi Belajar Siswa Pada Materi Pokok Kelarutan Dan Hasil Kali Kelarutan Kelas XI MIPA SMA Negeri 1 Banyudono Tahun Pelajaran 2014/2015" . Jurnal Pendidikan Kimia (JPK), Vol. 4 No. 4 Tahun 2015. 